\section{Pengembangan Bahan Ajar Berbasis E-Learning Mata Kuliah Fisika Dasar pada Jurusan Biologi FMIPA UNM}

\author{
Afiq Agung', Bunga Dara Amin², Ahmad Yani ${ }^{3}$ \\ dan Ahmad Swandi ${ }^{4}$
}

FMIPA Universitas Negeri Makassar ${ }^{1,2,3}$

Institut Teknologi Bandung 4

Email:arsyman@gmail.com

http://ojs.unm.ac.id/index.php/Insani/index

Abstrak. Penelitian ini mengembangkan bahan ajar dalam bentuk buku ajar dan dikemas dalam bentuk e-Learning. Materi yang diangkat adalah Fisika Dasar yang dikhususkan untuk Jurusan Biologi FMIPA UNM. Penelitian ini merupakan penelitian pengembangan. Hasil penelitian menunjukkan bahwa validasi terhadap bahan ajar dan materi dalam bahan ajar termasuk dalam kategori "sangat baik". Penilaian praktisi menunjukkan bahwa bahan ajar fisika dasar berbasis e-learning termasuk dalam kategori "sangat baik" sedangkan persepsi mahasiswa terhadap Bahan Ajar termasuk dalam kategori baik. Dengan demikian bahan ajar berbasis elearning materi fisika dasar untuk jurusan biologi layak digunakan dalam proses pembelajaran dalam perkuliahan fisika dasar di jurusan biologi.

Kata Kunci : Bahan Ajar, e-Learning, Fisika Dasar untuk Biologi.

\section{INDONESIAN JOURNAL OF EDUCATIONAL STUDIES (IJES)}

\section{E-ISSN: 2621-6744 \\ P-ISSN: 2621-6736}

Submitted: March $1^{\text {st }} 2018$

Accepted : May $25^{\text {th }} 2018$

Abstract. This study develops instructional materials in the form of textbooks and is packaged in the form of e-Learning. The material that was raised was Fundamental Physics devoted to Department of Biology FMIPA UNM. This is a Research and Development research with 3D model (define, design and development). The results showed that the validation of teaching materials and materials in teaching materials included in the category is "very good". The practitioners 'assessment showed that the basic physics teaching materials based on $e$ learning were included in the "very good" category while the students' perceptions of the Teaching Materials were included in the "good" category. Thus e-learning materials based on fundamental physics materials for biology department worthy of use in the process of learning in fundamental physics courses in biology department. 


\section{PENDAHULUAN}

Teknologi Informasi dan Komunikasi (TIK) yang terus berkembang memberikan dampak bagi berbagai bidang kehidupan manusia, salah satunya adalah bidang pendidikan. Pendidikan senantiasa bergerak maju seiring dengan pertumbuhan TIK yang semakin canggih. TIK dapat diberdayakan untuk mengembangkan media, materi dan bahan ajar yang lebih menarik, interaktif dan efektif. Dewasa ini, peserta didik sudah cukup akrab dengan penggunaan komputer dalam proses pembelajaran. Komputer adalah salah satu produk perkembangan TIK yang memungkinkan terciptanya proses pembelajaran mandiri (tanpa tatap muka). Seperti diketahui sebelumnya Materi pembelajaran yang sebelumnya berbasis kertas (paper based) terlalu menggunakan biaya besar dan material buang yang banyak sehingga berpindah dengan sistem berbasis elektronik (electronic based) akan mengefektifkan dan mengefisienkan hal tersebut. Dengan memanfaatkan komputer dan jaringan internet, peserta didik dapat termotivasi untuk belajar meskipun di luar lingkungan sekolah. Oleh karena itu Teknologi Informasi harus digunakan untuk mengembangkan dunia pendidikan.

Bidang pendidikan dewasa ini senantiasa terus bergerak maju seiring dengan pertumbuhan TIK yang semakin canggih. TIK dapat diberdayakan untuk mengembangkan media, materi dan bahan ajar yang lebih menarik, interaktif dan efektif. Heflin, Shewmaker, \& Nguyen (2017), menyatakan bahwa perkembangan TIK berhasil menciptakan peluang pengguanaan teknologi mobile dan tanpa wayar (wireless) dalam dunia pendidikan. Saat ini pun, kaum pelajar baik siswa maupun mahasiswa sudah cukup akrab dengan teknologi digital. Perangkat komputer telah banyak digunakan oleh banyak kalangan dan pelajar di semua jenjang Pendidikan. Komputer yang merupakan salah satu produk perkembangan TIK juga memungkinkan terciptanya proses pembelajaran mandiri (tanpa tatap muka). Dengan memanfaatkan komputer dan jaringan internet, peserta didik dapat termotivasi untuk belajar meskipun di luar lingkungan sekolah.

Mata kuliah Fisika Dasar adalah salah satu mata kuliah yang ditetapkan sebagai mata kuliah wajib hampir di seluruh jurusan di Fakultas Matematika dan Ilmu Pengetahuan Alam Universitas Negeri Makassar. Mata kuliah Fisika Dasar menjadi sangat penting sebab mata kuliah tersebut merupakan dasar dari beberapa mata kuliah selanjutnya yang berkaitan dengan disiplin ilmu fisika. Oleh karena itu pemahaman mahasiswa mengenai Fisika Dasar sangat penting. Dengan demikian, dibutuhkan suatu perangkat dalam proses pembelajaran yang dapat mempermudah mahasiswa dalam memahami Fisika Dasar lebih mudah lebih efisien.

Berdasarkan hasil observasi, keterbatasan waktu dalam pembelajaran dan tingkatan pokok bahasan mahasiswa terkadang menyebabkan beberapa materi tidak tuntas dibahas di dalam kelas. Kondisi seperti ini mengharuskan mahasiswa memiliki kemandirian belajar. Sumber belajar sebenarnya mudah didapatkan oleh mahasiswa namun terdapat konsep-konsep fisika yang cukup sulit untuk dipahami dengan sekadar membaca sehingga perlu suatu forum diskusi baik itu antar mahasiswa maupun antar mahasiswa dengan dosen.

Maka masalah-masalah yang telah dijelaskan di atas dapat diatasi dengan membentuk sebuah pembelajaran berbasis e-learning. Program komputer dalam 
pendidikan dapat dimanfaatkan sebagai lingkungan belajar yang efektif dan motivasional bagi peseta didik (Papastergiou, 2009). Selanjutnya Gündoğdu, Silman, \& Ozan (2011), mengemukakan bahwa melalui media komputer, materi pelajaran dapat lebih cepat diterima peserta didik secara utuh serta menarik minat mereka untuk belajar lebih lanjut. Pembelajaran e-learning adalah pembelajaran yang memanfaatkan teknologi yaitu komputer dan jaringan internet. Media merupakan prediktor pembelajaran yang signifikan bagi pesserta didik, termasuk mengendalikan faktor lain yang relevan seperti kecerdasan (Diergarten, Möckel, Nieding, \& Ohler, 2017). Media pembelajaran berbasis e-learning sangat sesuai dengan karakterisitik pembelajaran abad-21 yang dikenal sebagai generasi jaringan (net genaration) dan media ini dapat dimodifikasi sesuai dengan kebutuhan pengguna.

Penelitian yang dilakukan oleh Lau et al. (2018), dengan judul "The Role of Textbook Learning Resources in e-Learning: A Taxonomic Study" yaitu sebuah studi taksonomi mengenai peran sumber belajar teks dalam e-learning, hasilnya menunjukkan bahwa sumber belajar teks yang ada dapat berkontribusi dengan baik pada e-learning dan dapat diperoleh secara maksimal jika disertai dengan interaksi dan kolaborasi yang luas antara peserta didik dan fasilitator di lingkungan e-learning. Amin \& Swandi (2016), telah melakukan penelitian pengembangan bahan ajar yaitu Lembar Kerja Siswa (LKS) berdasarkan simulasi virtual yang dapat diakses melalui $e$ learning. Hasil penelitian tersebut menunjukkan bahwa LKS berdasarkan simulasi virtual dinyatakan valid. Dan hasil persentase $\mathrm{N}$-gain untuk mengevaluasi siswa menunjukkan bahwa penerapan lembar kerja siswa tersebut dapat meningkatkan hasil belajar siswa di tingkat tinggi. Kemudian Bicen, Ozdamli, \& Uzunboylu (2014), juga melaksanakan penelitian terkait pembelajaran online (e-learning). Hasil penelitian menunjukkan calon guru dalam kelompok yang mengembangkan elearning disertakan pertemuan (tatap muka) lebih efektif. Selain itu juga Grieve, Padgett, \& Moffitt (2016), melaksanakan penelitian pada peserta didik kalangan mahasiswa tentang membandingkan efektifitas penugasan secara online versus offline di perguruan tinggi. Temuan penelitian menunjukkan bahwa modalitas umpan balik online akan memaksimalkan keterlibatan mahasiswa dengan efektif jika penanda tugas dan alat umpan balik secara online memfasilitasi persepsi kehadiran sosial.

Hasil observasi pula menunjukkan penggunaan media pembelajaran berbasis elearning sangat memungkinkan untuk dilakukan di Jurusan Biologi melihat semua mahasiswa sudah mampu mengakses internet dan mengoperasikan komputer dengan baik. Media e-learning yang dikembangkan hendaknya memuat seluruh materi fisika dasar dan forum diskusi. Berdasarkan latar belakang di atas maka peneliti berinisiatif untuk melakukan penelitian yang mengembangkan sebuah bahan ajar dengan judul penelitian "Pengembangan Bahan Ajar berbasis e-Learning Mata Kuliah Fisika Dasar pada Jurusan Biologi FMIPA UNM”.

\section{METODE PENELITIAN}

Penelitian ini adalah penelitian pengembangan yang menggunakan model 3-D (Three-D Model) yaitu modifikasi dari model 4-D (Four-D Model) yang dikembangkan oleh S. Thiagarajan meliputi tahap Pendefinisian (Define), Perencanaaan (Design), Pengembangan (Develop), dan Penyebaran (Disseminate). Namun, karena 
keterbatasan waktu dan dana, tahapan terakhir dari 4-D yaitu disseminate tidak dilaksanakan dalam penelitian ini. Penelitian ini dilaksanakan di Jurusan Biologi Fakultas Matematika dan IImu Pengetahuan Alam (FMIPA) Universitas Negeri Makassar (UNM). Dilaknasakan pada Semester Ganjil Tahun Ajaran 2017/2018. Subjek penelitian ini adalah bahan ajar berbasis e-learning pada materi Fisika Dasar.

Berikut adalah defenisi operasional beberapa variabel dalam penelitian ini.

1. Bahan ajar berbasis e-learning adalah bahan ajar berupa media yang berbasis elearning (seperti buku ajar namun dalam bentuk e-learning) yang memanfaatkan komputer dan jaringan internet yang menampilkan serangkaian materi, fasilitas chat serta forum diskusi yang dapat diakses secara online.

2. Penilaian praktisi/dosen adalah pemberian skor oleh praktisi/dosen pada lembar penilaian yang menggambarkan kualitas materi dan media pembelajaran yang meliputi aspek kualitas tampilan, daya tarik, teknis, navigasi, fleksibilitas, materi dan kebahasaan. Penilaian praktisi/dosen dapat dilihat melalui lembar persepsi yang dibagikan pada akhir pembelajaran.

3. Persepsi mahasiswa adalah tanggapan mahasiswa terhadap kegiatan pembelajaran dengan menggunakan bahan ajar yang meliputi aspek kualitas tampilan, daya tarik, teknis, navigasi, dan fleksibilitas. Persepsi mahasiswa dapat dilihat melalui lembar persepsi yang dibagikan pada akhir pembelajaran.

Data yang diperoleh dari penelitian ini berupa data hasil validasi oleh validator ahli, data angket hasil penilaian dosen dan data angket hasil persepsi mahasiswa. Instrumen penelitian yang digunakan yaitu lembar validasi, angket penilaian dosen dan angket persepsi mahasiswa. Lembar validasi diberikan kepada validator ahli untuk mengetahui kelayakan bahan ajar serta materi didalamnya dan mendapatkan saran untuk perbaikan. Kegiatan dengan pengisian angket penilaian dosen oleh dosen fisika dasar dan pengisian angket persepsi mahasiswa oleh mahasiswa biologi kelas Biologi ICP 2017.

\section{HASIL DAN PEMBAHASAN}

\section{Analisis Awal-Akhir}

Mahasiswa kini sebahagian besar telah memiliki handphone yang dapat mengakses internet. Untuk itu diharapkan sebuah solusi yang dapat memberikan pengalaman belajar lebih bagi mahasiswa dan memudahkan dalam menangkap materi pembelajaran. Selain itu juga sesuai dengan perkembangan TIK dan karakteristik mahasiswa. Dengan adanya sebuah bahan ajar yang memuat materi yang dapat diakses kapan saja membuat pembelajaran berlangsung lebih fleksibel, mudah, dan menyenangkan. Interaksi antar mahasiswa maupun antar mahasiswa dengan dosen dapat terjalin dengan baik melalui layanan interaksi forum diskusi.

\section{Analisis Mahasiswa}

Mahasiswa memiliki kemampuan dalam menggunakan komputer dan smartphone serta dapat mengakses internet dengan baik. Mahasiswa pada umumnya berusia 18 tahun ke atas, pada usia ini telah memasuki tahap operasional formal menurut Piaget, yaitu berada pada usia 12 tahun sampai usia dewasa (Ibda, 2015). Dengan demikian mahasiswa mampu belajar mandiri meskipun telah berada di luar ruang kuliah. Melalui kemampuan tersebut, e-learning dapat membantu kemandirian 
mahasiswa untuk belajar dan menambah pengetahuannya melalui informasi yang ia peroleh.

\section{Analisis Konsep}

Struktur materi Fisika Dasar untuk Biologi terdiri dari sembilan bab, dapat dilihat pada tabel 4 .

Tabel 1. Materi dalam setiap Bab.

\begin{tabular}{ccl}
\hline No. & Bab & Materi \\
\hline 1 & I & Pendahuluan \\
\hline 2 & II & Biomekanika \\
\hline 3 & III & Suhu dan Kalor \\
\hline 4 & IV & Bunyi \\
\hline 5 & V & Fluida \\
\hline 6 & VI & Sterilisasi \\
\hline 7 & VII & Biolistrik \\
\hline 8 & VIII & Bio Optik \\
\hline 9 & IX & Atom dan Radiasi \\
\hline
\end{tabular}

\section{Analisis Tugas}

Analisis tugas berfokus pada pencapaian tujuan pembelajaran. Penentuan jenis tugas didasarkan pada hasil analisis konsep dan karakteristik mahasiswa. Berdasarkan hasil analisis tersebut, tugas yang diberikan pada mahasiswa berupa evaluasi materi pada bahan ajar yang diberikan setiap bab. Tugas ini dapat diselesaikan selama pembelajaran di dalam kelas dan dapat pula dikerjakan diluar pembelajaran, tugas tersebut dapat diperoleh dari e-learning.

\section{Analisis Bahan Ajar}

Bahan ajar yang dikembangkan dalam penelitian ini adalah buku ajar namun dikembangkan dengan berbasis online/e-learning. Sehingga peneliti terlebih dahulu melakukan analisis mengenai buku ajar fisika dasar yang digunakan dalam perguruan tinggi khususnya bidang atau jurusan biologi. Lebih terkhusus lagi di Jurusan Biologi Fakultas Matematika dan Ilmu Pengetahuan Alam Universitas Negeri Makassar. Analisis ini perlu untuk dilakukan sebab berhubungan dengan permasalahan yang ingin ditemukan solusinya yaitu mengenai bahan ajar khususnya buku ajar.

Ada banyak buku-buku fisika dasar yang telah ditemui dan dianalisis oleh peneliti. Pertama adalah buku fisika dasar yang diterapkan di jurusan biologi namun buku tersebut tidak khusus diperuntukkan mahasiswa jurusan biologi, yaitu buku fisika dasar umum atau buku fisika dasar untuk mahasiswa jurusan fisika. Kedua adalah buku fisika dasar yang digunakan di jurusan biologi namun diperuntukkan untuk mahasiswa kesehatan atau kedokteran. Dengan demikian, peneliti memilih untuk mengembangkan bahan ajar yaitu buku ajar Fisika Dasar khusus untuk mahasiswa biologi. Buku ajar ini berbasis e-learning atau dapat diakses secara online.

\section{Analisis Kurikulum}

Fisika Dasar adalah mata kuliah wajib di jurusan Biologi FMIPA UNM yang diprogramkan pada semester ganjil. Memiliki jumlah SKS 3, yang keseluruhannya terhitung dalam perkuliahan tatap muka. Mata kuliah Fisika Dasar untuk Jurusan 
Biologi tersebut terdiri dari materi Biomekanika, Termodinamika, Bunyi, Fluida, Sterilisasi, Biolistrik, Bio Optik, Atom dan Radiasi. Evaluasi materi dilakukan setiap bab dalam perkuliahan yang dibuat dalam bentuk tugas. Jumlah pertemuan sebanyak 16 pertemuan.

Alur pengembangan bahan ajar berbasis e-learning materi Fisika Dasar dimulai dengan membuat e-learning. Pembuatan e-learning tersebut menggunakan layanan e-learning dari Gnomio.com. Gnomio merupakan website penyedia pembuatan elearning yang dibuat oleh komunitas Moodle yang terdiri dari beberapa pembuat Moodle di dunia (Gnomio, 2017). Kelebihan dari e-learning moodle dari Gnomio ini mempunyai lebih banyak fitur yang dapat dikelola dengan mudah selain MoodleCloud. MoodleCloud adalah sebuah penyedia hosting e-learning moodle yang lain namun dibatasi hanya 50 pengguna/peserta didik setiap kelas dengan kapasitas penyimpanan (disk space) maksimal 200 MB (Tuparova, Al-sabri, \& Tuparov, 2018). Gnomio sebagai solusi hosting moodle yang telah terkelola dengan baik. Moodle (Modular Object-Oriented Dynamic Learning Environment) merupakan salah satu aplikasi LMS (Learning Management System) berbasiskan web. LMS adalah sistem perangkat lunak yang dirancang untuk memfasilitasi tugas administratif serta partisipasi siswa dalam materi e-learning (Sejzi \& Aris, 2013).

Salah satu kelebihan dari bahan ajar yang dibuat dengan moodle gnomio ini adalah persamaan fisika-nya di buat dengan script atau kode TeX Notation. Hal ini akan membuat halaman web/bahan ajar akan lebih ringan dan cepat loading. TeX Notation adalah sistem notasi atau sistem typesetting atau metafont untuk mendeskrpsikan font dalam bentuk persamaan matematika dalam dokumen dan dapat digunakan dalam halaman html (Hildebrand, 2007). Telah dilaksanakan pula riset oleh Gaudeul (2007), menyampaikan bahwa TeX adalah program pengarsipan open source berbasis type setting yang dirancang dengan tujuan utama untuk menyediakan sistem yang akan memberikan hasil yang sama persis pada semua komputer (dapat diakses oleh berbagai pengguna), dan kapan saja.

Berdasarkan analisis penilaian oleh dua validator, diperoleh bahwa pada penilaian media dan materi yang terdapat pada bahan ajar diperoleh hasil yang sangat baik untuk setiap aspek penilaian. Dimana persentase rata-rata untuk penilaian media dan materi masing-masing adalah 92,8125\% dan 96,24\%. Setelah dilakukan penilaian oleh dua orang ahli baik materi maupun ahli media, bahan ajar telah dinyatakan valid. Dimana nilai validity contain yang diperoleh untuk bahan ajar maupun materi adalah 1,0.

Penelitian yang dilakukan oleh Hartawan, Tastra, \& Pudjawan (2014), menunjukkan bahwa pembelajaran dengan menggunakan portal e-learning dapat meningkatkan hasil belajar mahasiswa kelas X di SMA Dwijendra Denpasar pada mata pelajaran Fisika pokok bahasan teori kinetik gas. Sedangkan Pelupessy \& T. Agustin (2014), juga menemukan bahwa media pembelajaran berbasis e-learning pada mata kuliah Fisika 1 memiliki nilai efektifitas yang tinggi yaitu sebesar $86 \%$. Dari temuantemuan yang diperoleh di lapangan serta dukungan oleh beberapa hasil penelitian maka dapat dikatakan bahwa bahan ajar berbasis e-learning memudahkan peserta didik dalam belajar fisika. Bahan ajar berbasis e-learning juga memungkinkan terjalinnya interaksi antar mahasiswa maupun antara mahasiswa dengan dosen. 
Website yang dapat diakses kapan dan dimana saja telah membangun proses pembelajaran yang fleksibel. Kemudahan-kemudahan yang ditemui pada bahan ajar ini menjadi keunggulan tersendiri yang tidak dimiliki oleh jenis media yang lain. Bahkan Yazdi (2012), melalui penelitian tentang e-Learning sebagai media pembelajaran interaktif menemukan bahwa ketertarikan mahasiswa terhadap pembelajaran menjadi meningkat.

Berdasarkan hasil analisis penilaian dosen terhadap bahan ajar berbasis elearning diperoleh persentase rata-rata sebesar 97,32\% yang termasuk dalam kategori sangat baik. Nilai tersebut menunjukkan bahwa dosen setuju dengan penggunaan bahan ajar berbasis e-learning dalam pembelajaran fisika dasar yaitu pada jurusan biologi. Hasil tersebut diperoleh melalui penilaian yang meliputi beberapa aspek diantaranya kualitas tampilan, daya tarik, navigasi, teknis, materi, kebahasaan, dan fleksibilitas media. Persentase penilaian tertinggi pada Gambar 2 terdapat pada semua aspek kecuali pada aspek teknis. Aspek selain aspek teknis kesemuanya memperoleh persentase 100\%, sedangkan aspek teknis memperoleh persentase $81.25 \%$. Hal ini membuat setiap aspek masuk dalam kategori sangat baik.

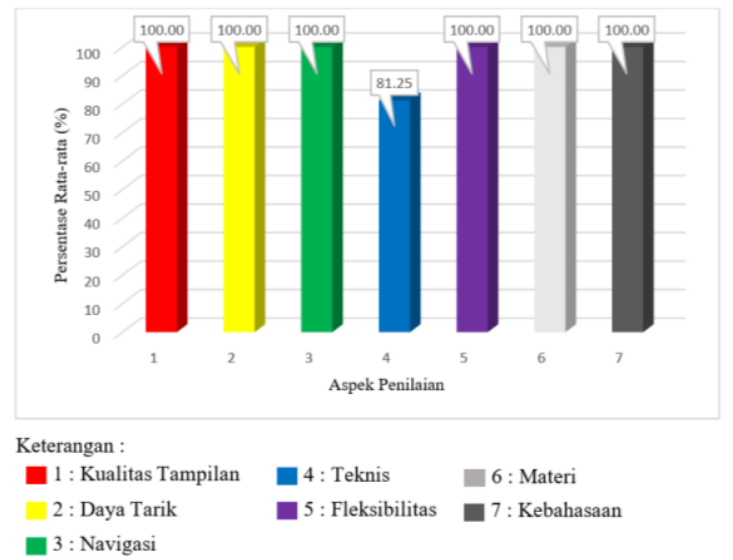

Gambar 1. Persentase Rata-rata Penilaian praktisi/dosen terhadap setiap aspek.

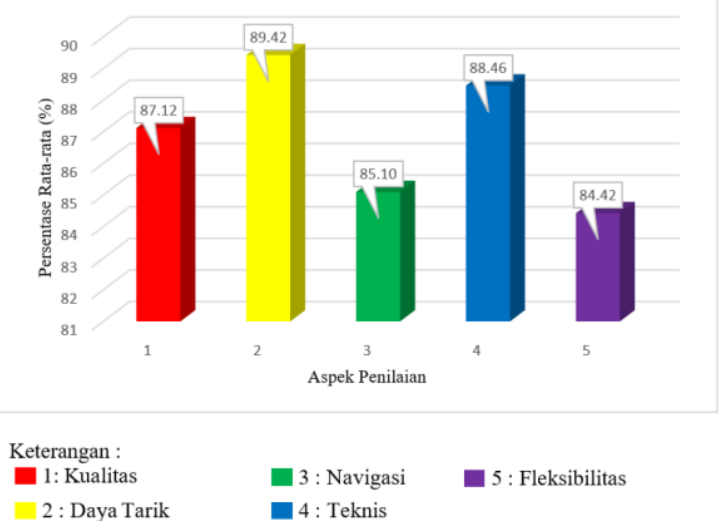

Gambar 2. Persentase Rata-rata Persepsi

Mahasiswa Terhadap Setiap Aspek

Berdasarkan hasil analisis data diperoleh persentase rata-rata persepsi mahasiswa terhadap bahan ajar berbasis e-learning sebesar $86,60 \%$. Nilai ini berada 
pada kategori baik yang berarti mahasiswa setuju dengan penggunaan bahan ajar ini. Berdasarkan Gambar 3, terlihat bahwa persentase penilaian yang paling tinggi terletak pada daya tarik yakni sebesar $89,42 \%$. Hal ini menunjukkan bahwa e-learning dinilai menarik oleh mahasiswa.

\section{KESIMPULAN}

Profil Bahan Ajar berbasis e-Learning mata kuliah Fisika Dasar yang dikembangkan adalah sebuah website yang didalamnya terdapat materi yang dikemas mirip sebuah buku (terdiri dari beberapa bagian/bab) dilengkapi keterangan gambar, persamaan, dan grafik. Berdasarkan penilaian oleh dua validator terhadap bahan ajar dan materi dalam bahan ajar diperoleh rata-rata hasil persentase sebesar 92,8125\% dan 96,24\% yang berarti bahan ajar dan materi dalam bahan ajar termasuk dalam kategori sangat baik. Sedangkan hasil analisis terhadap penilaian oleh ahli bahan ajar dan materi dalam bahan ajar menunjukkan bahan ajar berbasis e-learning dinyatakan valid dengan nilai VC sebesar 1,0.

Penilaian praktisi/dosen terhadap Bahan Ajar berbasis e-Learning materi Fisika Dasar menunjukkan nilai persentase rata-rata sebesar $97,32 \%$ yang menunjukkan bahwa bahan ajar fisika dasar berbasis e-learning termasuk dalam kategori "sangat baik". Aspek-aspek pada bahan ajar yang dinilai oleh praktisi adalah Kualitas Tampilan, Daya Tarik, Navigasi, Teknis, Fleksibilitas, Materi dan Kebahasaan. Hasil penilaian tersebut menunjukkan bahwa semua aspek bahan ajar tersebut masuk dalam kategori "sangat baik" kecuali aspek teknis yang masuk dalam kategori "baik". Persepsi mahasiswa terhadap Bahan Ajar berbasis e-Learning materi Fisika Dasar menunjukkan nilai persentase rata-rata sebesar $86,60 \%$ yang termasuk dalam kategori baik. Aspek-aspek yang dinilai dalam penilaian oleh mahasiswa adalah Kualitas Tampilan, Daya Tarik, Navigasi, Teknis dan Fleksibilitas. Hasil penilaian menunjukkan bahan ajar pada aspek Daya Tarik dan Teknis masuk dalam kategori "sangat baik", sedangkan bahan ajar pada aspek Kaulitas Tampilan, Navigasi dan Fleksibilitas masuk dalam kategori "baik".

\section{DAFTAR PUSTAKA}

Amin, B. D., \& Swandi, A. (2016). The Development of Student's Worksheet of Physics Based on Virtual Simulation and Its Influence on Physics Learning Outcomes of Students. In International Conference on Mathematics, Science, Technology, Education, and their Applications (ICMSTEA) (Vol. 7, pp. 22-28).

Bicen, H., Ozdamli, F., \& Uzunboylu, H. (2014). Online and blended learning approach on instructional multimedia development courses in teacher education. Interactive Learning Environments, 22(4), 529-548. https://doi.org/10.1080/10494820.2012.682586

Diergarten, A. K., Möckel, T., Nieding, G., \& Ohler, P. (2017). The impact of media literacy on children's learning from films and hypermedia. Journal of Applied Developmental Psychology, 48, 33-41. https://doi.org/10.1016/j.appdev.2016.11.007

Gaudeul, A. (2007). Do Open Source Developers Respond to Competition? The TEX Study Case. Review of Network Economics, 6(2), 239. https://doi.org/10.2202/1446-9022.1119 
Gnomio. (2017). Gnomio: Discover The Ultimate e-Learning Tool.

Gregory, R. J. (2007). Psycological Testing: History, Principal and Aplications. Boston: Allyn and Bacon.

Grieve, R., Padgett, C. R., \& Moffitt, R. L. (2016). Assignments 2.0: The role of social presence and computer attitudes in student preferences for online versus offline marking. Internet and Higher Education, 28, 8-16. https://doi.org/10.1016/j.iheduc.2015.08.002

Gündoğdu, K., Silman, F., \& Ozan, C. (2011). A comparative study on perception of teachers on the use of computers. International Online Journal of Educational Sciences, 3(1), 113-137.

Hartawan, I. K. A., Tastra, I. D. K., \& Pudjawan, K. (2014). Pengembangan Portal eLearning Berbasis Moodle pada Mata Pelajaran Fisika Kelas X di SMA Dwijendra Denpasar. E-Journal Edutech Universitas Pendidikan Ganesha, 2(1).

Heflin, H., Shewmaker, J., \& Nguyen, J. (2017). Impact of mobile technology on student attitudes, engagement, and learning. Computers and Education, 107, 9199. https://doi.org/10.1016/j.compedu.2017.01.006

Hildebrand, A. J. (2007). Introduction to TEX /LATEX - UIUC Department of Mathematics Graduate Student Orientation Fall 2007.

Ibda, F. (2015). Perkembangan Kognitif: Teori Jean Piaget. Jurnal Intelektualita, 3(1), 27-38.

Lau, K. H., Lam, T., Kam, B. H., Nkhoma, M., Richardson, J., \& Thomas, S. (2018). The role of textbook learning resources in e-learning: A taxonomic study. Computers and Education, 118, 10-24. https://doi.org/10.1016/j.compedu.2017.11.005

Papastergiou, M. (2009). Digital Game-Based Learning in high school Computer Science education: Impact on educational effectiveness and student motivation. $\begin{array}{lll}\text { Computers and } & \text { 52(1), }\end{array}$ https://doi.org/10.1016/j.compedu.2008.06.004

Pelupessy, E. T., \& T. Agustin, H. P. (2014). Pengembangan Media Pembelajaran Berbasis E-Learning Pada Mata Kuliah Fisika 1 Untuk Meningkatkan Efektifitas Belajar Mahasiswa. Jurnal Pendidikan Teknik Elektro, 3(2), 193-198.

Riduwan. (2011). Dasar-dasar Statistika. Bandung: Penerbit Alfabeta.

Sejzi, A. A., \& Aris, B. (2013). Learning Management System ( LMS ) and Learning Content Management System ( LCMS ) at Virtual University. 2nd International Seminar on Quality and Affordable Education, 216-220.

Tuparova, D., Al-sabri, A. R., \& Tuparov, G. (2018). Teaching and Learning in a Digital World, 715. https://doi.org/10.1007/978-3-319-73210-7

Yazdi, M. (2012). E-Learning Sebagai Media Pembelajaran Interaktif Berbasis Teknologi Informasi. Jurnal Ilmiah Foristek, 2(1), 143-152. Retrieved from http://jurnal.untad.ac.id/jurnal/index.php/FORISTEK/article/view/665/584 